Law in the Digital Age. 2021. Vol. 2, no. 3.

Вопросы права в цифровую эпоху. 2021. Т. 2. № 3.

Research article

УДК 342.951

DOI: $10.17323 / 2713-2749.2021 .3 .33 .57$

\title{
Prospects of Legal Regulating Use of Driverless Transportation Vehicles in the Russian Federation
}

\section{凡目 Aleksei G. Deineko}

National Research University Higher School of Economics, Moscow, Russia, alexey-deyneko@mail.ru, orcid:0000-0003-3700-7364

\section{㗖目 Abstract}

The article reviews the new Russian legislation introducing the experimental legal regime for the use of highly automated transportation vehicles (HATVs) (driverless vehicles) on public roads. The article analyzes strategic planning documents related to the subject, such as the governmental Traffic Safety Concept for Public Roads with Driverless Transportation Vehicles (DTVs) and the European Union's documents regulating the use of robots and artificial intelligence (Al). Drafts of the relevant laws presently at the stage of public debate or discussion at the Duma are reviewed. The Russian experience of legal regulation is compared to the international experience, with conclusions made about possible directions for the development of the legislation. The article broaches the issues of apportioning tort and administrative liability for damage caused by the use of HATVs or as a result of a breach of the road rules by such vehicles. The obvious hurdles in the way of imposing liability on a robot or an Al algorithm underscore the need to hold on to the classic tort liability model adjudicating claims of damage caused by hazardous objects and modify this model to make is usable for situations when damage is caused by a DTV. In a separate section, this article addresses issues related to the use of delivery robots - the objects do not fit the definition of transportation vehicles provided in the road rules and in the drafts of legal acts currently being prepared. The conclusion is made that judicial opinions should provide clarifications for accidents involving such vehicles because, moving along sidewalks and crossing traffic areas, they are actually road users. As for risks for personal rights and freedoms associated with the use of DTVs, this writer focuses on risks related to the collection and use of passengers' personal data, as well as risks of mass layoffs arising from the probable decline in demand 
for taxi and truck drivers and street traffic controllers. Relying on the results of the analysis, this author suggests how to proceed with the legal regulation of the use of HATVs and reflects on legal and socio-economic implications of their large-scale use in Russia.

\section{O-y 圆 Keywords}

theory of law, information law, artificial intelligence, robotics, driverless vehicles, robotic vehicles, digitization, experimental legal regimes, regulatory sandbox, information security.

For citation: Deineko A.G. Prospects of Legal Regulating Use of Driverless Transportation Vehicles in the Russian Federation. Legal Issues in the Digital Age. 2021, no. 3, pp. 33-57. DOI: 10.17323/2713-2749.2021.3.33.57

\section{Introduction}

In recent years our country has seen great technological advancements in designing and developing a new generation of transportation vehicles, which can drive autonomously, without direct human inputs. The research and development of the new technologies is currently focused on several areas: development of driver assistance technologies and analogs of "autopilot" in production vehicles; creating, on the basis of these systems, experimental DTV models and designing so-called "intelligent roads" compatible with the new types of vehicles that drive taking cues from digital markers and notifications. As for the Russian market, which, according to analysts ${ }^{1}$, is bound to experience a boom as soon as the nearest decade, its leaders include Yandex SDC, SberAutoTech, and KamAZ.

The Covid-19 pandemic - or, rather, the associated risks and anti-pandemic restrictions - is also likely to contribute to the development of driverless vehicles. Driverless taxis, whose passengers do not have to come into contact with drivers, and driverless deliveries of purchased goods, whereby couriers does not get in touch with sellers and buyers, are obviously much safer options than the alternatives, given the persistent dangers to people's life and health. One would assume that consumers will keep a positive attitude to these technologies even after the lifting of the COVID-related restrictions because the models of social behavior shaped by the pandemic

${ }^{1}$ See, for instance: Yandex’s Unmanned Vehicles Business Worth $\$ 7$ Billion: Estimate. Forbes, Aug.5, 2021. Available at: URL: https://forbes.ru/tehnologii/436537-bespilotnyybiznes-yandeksa-ocenili-v-7-mlrd (accessed: Oct. 1, 2021) 
cannot disappear in an instant. Besides, according to economists' estimate, a large-scale use of driverless deliveries can produce positive economic effects due to dramatic cuts in transportation costs caused by fuel savings [Lazutkina V.V., Pokusaev O.N. et al., 2018: 66-80], is expected to contributed to a decline in the numbers of road traffic accidents [Shaklein A.G., Pokusaev O.N. et al., 2019: 104-114] and, as a result, may reduce the final costs of goods and services.

In 2016 this writer attempted to outline main problems related to the absence (then) of legal regulation of the use of DTVs in our country. In particular, this writer highlighted three key clusters of legal issues:

absence of a legal definition and classification of driverless vehicles;

absence of a legal framework for granting DTVs access to public roads (state registration of DTVs is impossible, the issues of compatibility of the national and supranational regulatory frameworks, etc.);

mootness of the issues of assigning liability for damage caused by the use of a DTV.

And referencing countries that attempt to "legalize" the use of DTVs, this writer, in his 2016 study, mentioned the USA and Asian countries, which carry out experiments in legal regulation of the field in specially designated regions. Thus, in the USA DTVs may be used mostly in small towns in several American southern states, and in Michigan such vehicles do not even need to have an engineer in the driver's seat. At the same time, researchers point out that the American lawmakers have to tackle the problem of apportioning liability for road traffic accidents involving DTVs, which slows down the process of DTVs-related lawmaking [Voronin D.A., Makarevich M.L., 2018: 126].

The countries such as the USA, China, Singapore and Japan enjoy a greater freedom in the matters of legal regulation of road traffic since they are not signatories of the 1968 Vienna Convention on Road Traffic ${ }^{2}$, which the Russian Federation (Russia) have joined in 1993. "The stumbling block" for the convention's signatories is its provisions whereby "every moving vehicle or combination of vehicles shall have a driver" (Art. 8 (1), who "shall possess the necessary physical and mental ability and be in a fit physical and mental condition to drive" (Art. 8 (3) and who "shall at all times be able to control his vehicle" (Art.8 (5). A literary interpretation of the Vienna

2 The Convention on Road Traffic (adopted in Vienna Nov. 8, 1968, amended Sept. 23, 2014). Available at: https://unece.org/fileadmin/DAM/trans/conventn/Conv_road_traffic_EN.pdf (accessed: Oct. 1, 2021) 
convention's thesaurus suggests that the document rules out the possibility of a self-driving vehicle without a human in the driver's seat - in any case, vehicles without drivers most certainly were simply not a feasible option to consider at the time when the convention was adopted.

In 2014, at its $68^{\text {th }}$ session, the Working Party on Road Traffic Safety of UN's Inland Transport Committee has adopted amendments to the Convention initiated by several European countries and complementing Art.8 with clause 5-bis, "legalizing" the use of autonomous control systems for transportation vehicles. These amendments were published on September 23, 2014, and came into force, for the Russia and the Convention's other signatories, on March 23, 2016. Analyzing these amendments, legal scholar A.V. Neznamov remarked that one of the necessary conditions for using such autonomous systems was the presence of the option of switching them off, which the driver could avail himself of at any moment, so claiming that we witness a full "legalization of completely autonomous vehicles is a little too soon” [Neznamov A.V., 2018: 178].

It can be argued, however, that a more liberal approach to interpreting these provisions of the Convention is possible since the document does not directly require that the driver with the necessary psychological and physical qualities be seated inside the vehicle. This writer believes that the Convention's version presently in force implicitly provides that the operator can be situated in a DTV s control center. In line with the amendments adopted in 2014, this operator is capable of switching off the automated system and assuming the responsibility for driving the vehicle in a situation when the vehicle is "confused." A case in point is a situation when a DTV driving along a single-lane road encounters the scene of a road accident and, due to the presence of road surface markings, cannot bypass this site. Under such circumstances, the operator can examine videos from the DTV's external surveillance cameras and, making sure that crossing into an oncoming lane would be safe, give the vehicle a one-time permission to do so.

If such an interpretation is to be adopted, it can be assumed that the legalization of the use of DTVs in our country presently would not require amendments to the international legislation and can be effected at a national level. Moreover, Russian lawmakers already took first steps in this direction.

\section{Legislative innovations}

In 2018 the public authorities set about addressing the issues mentioned above, following in the American footsteps to some extent in terms of regu- 
lation. In its Order No.1415 the Russian government introduced Regulations Concerning the Pilot Project of Using Highly Automated Transportation Vehicles (HATVs) on Public Roads ${ }^{3}$ (hereinafter referred to as the Regulations), whereby the experiment is to run between December 1, 2018, and March 1, 2022, in Moscow and the Republic of Tatarstan. This writer concurs with legal scholar A. V. Neznamov, who pointed out that these two regions are probably unlikely to provide sufficient data for the nationwide introduction of HATVs because roads in these regions are superior to those that can be found elsewhere in Russia whereas the selected regions themselves are more or less similar in terms of climate and topography (Komarov S.V., Stolbova N.V., Neznamov A.V. et al., 2019: 60].

In March 2020 other regions joined the experiment: Vladimirskaya, Leningradskaya, Moskovskaya, Nizhegorodskaya, Novgorodskaya and Samarskaya Oblasts (provinces), Republic of Chuvashia, Khanty-Mansi and Yamalo-Nenets Autonomous Okrugs (autonomous areas), Krasnodarsky Krai (region), and Saint Petersburg. The addition of new Russian regions to the list of the experiment's participants is an evidence of a great economic attractiveness of the new technologies since the mentioned regions, leaders of the national economy, are regarded as attractive by investors. Besides, such expansion testifies to a certain level of HATVs' safety, proven during the first years of the experiment. As this writer's has learned monitoring the news, perhaps the only road accident for which an HATV was "responsible" took place in Moscow in 2019, caused by the driving engineer's error. In the other known cases of road accidents involving HATVs, drivers of ordinary vehicles were the responsible party.

The Regulations were provided with a legal foundation post factum, with the adoption of Federal Law No. 258-FZ (July 31, 2020) On Digital Innovation Experimental Legal Regimes in the Russian Federation ${ }^{4}$. Although this law was adopted one year and a half, and came into force two years, after the experiment's start, its Art. 2(2), referencing main directions of the

${ }^{3}$ Order No. 1415 of the Russian Federation Government. Nov. 26, 2018. On the Pilot Project of Using Highly Automated Transportation Vehicles on Public Roads [O provedenii eksperimenta po opytnoy ekspluatatsii na avtomobil'nykh dorogakh obshchego pol'zovaniya vysokoavtomatizirovannykh transportnykh sredstv] (as amended on Febr. 22, 2020). Compendium of Laws of the Russian Federation [Sobranie zakonodatel'stva Rossiyskoy Federatsii]. Dec. 3, 2018. No. 49 (part VI), Art. 7619.

${ }^{4}$ Federal law No. 258-FZ July 31, 2020, as amended July 2, 2021 "On Experimental Legal Regimes in the Area of Digital Innovation in the Russian Federation" [Ob eksperimental'nykh pravovykh rezhimakh v sfere tsifrovykh innovatsiy v Rossiyskoy Federatsii]. Available at: URL: www.pravo.gov.ru (accessed: Oct. 1, 2021) 
experimental legal regimes, mentions design, manufacturing and using transportation vehicles, including HATVs and driverless aerial vehicles.

It needs to be mentioned that from the constitutional point of view the idea of introducing experimental legal regimes may appear questionable. If we posit that: the utilization of HATVs in any given region of the Russia increases the chances of road accidents for this region's residents in comparison to residents of non-participating regions, and residents of such designated region who do not wish to participate in the legal experiment essentially have no choice, then it would be safe to conclude that the introduction of the experimental legal regimes is at variance with the general legal principle of equality and non-discrimination ${ }^{5}$. As a possible counterargument to the above statement, one can say that the AI systems responsible for HATVs are much more "disciplined" than the average driver, whereas AI's level of concentration on driving is likewise much greater since driving is the only thing on which HATV s' operation systems can focus their attention. One would assume that a definitive answer to this question should be given by the Russian Federation's Constitutional Court, if the constitutionality of the mentioned federal law is questioned.

As legal scholar V. O. Makarov notes, the model of experimental legal regimes ("regulatory sandboxes") is not something unique to our country as it is widely used internationally. Under this model, the state temporarily exempts companies developing new technologies from existing regulations in order to test the hypothesis that outdated legal norms should be abolished [Makarov V.O., 2020: 18-24]. Such approach, in our opinion, is more prudent than legislating "by intuition," relaying on lawmakers' ideas of what is good and what is bad. One would assume that when the regional experiments on the use of HATVs are over, the next necessary step to take would be to consider introducing relevant amendments to the federal legislation.

\section{Issues of terminology}

According to the Regulations, an HATV is a transportation vehicle released in the Eurasian Economic Union and authorized for use as a transportation vehicle in the Russian Federation, whose factory-made equipment has been complemented with an automated driving system and whose

${ }^{5}$ Article 19 of the Constitution of the Russian Federation. Adopted by national referendum on Dec.12, 1993, as amended by national referendum on July 1, 2020. Available at: URL: www.pravo.gov.ru (accessed: Sept. 1, 2021) 
ownership cannot be transferred to any other party while the experiment is underway. We are talking here not about half-baked products at the stage of development which have not been certified, tested for safety and undergone other necessary procedures, but about transportation vehicles which, while not yet common in the stream of commerce, have been certified as fit for use and re-designed to become autonomous. At the experimental stage, owners of HATV s may not enter into transactions transferring ownership rights to their vehicles to any third parties.

It should be noted that the Society of Automotive Engineers (SAE) International developed "a taxonomy with detailed definitions for six levels of driving automation"':

level 0 - a vehicle entirely operated and controlled by a human being ("No Driving Automation");

level 1 - human-operated vehicle is equipped with basic automation features (for instance, cruise control and road markings compliance) ("Driver Assistance");

level 2, when a vehicle can drive a certain distance in a real road environment in autopilot mode (this technology is known as adaptive cruise control) ("Partial Driving Automation");

level 3, when a vehicle can autonomously overtake other vehicles and safely exit a road (“Conditional Driving Automation");

level 4, when a vehicle drives autonomously and chooses a route, but in difficult situations (a road accident or a strong deterioration of the weather) the vehicle operation is taken over by a human driver ("High Driving Automation");

level 5, a fully autonomous (driverless) vehicle [for more information about this, see [Shadrin S.S., Ivanova A.A., 2019] ("Full Driving Automation").

This taxonomy is important as a guidance for various models of apportioning tort liability because even a partial discharge from this liability can be granted to the driver only in case of the $4^{\text {th }}$ or $5^{\text {th }}$ levels of automation. As for possible accidents related to failures of the "driver's assistants" in ve-

${ }^{6}$ Society of Automotive Engineers (SAE) International, standard J3016_202104. Taxonomy and Definitions for Terms Related to Driving Automation Systems for On-Road Motor Vehicles. (revised on April 30, 2021). Available at: https://sae.org/standards/content/j3016_202104 (accessed: Oct.1, 2021). The Russian text of this article contains the translation of excerpts from the Standards accomplished by the article's author. 


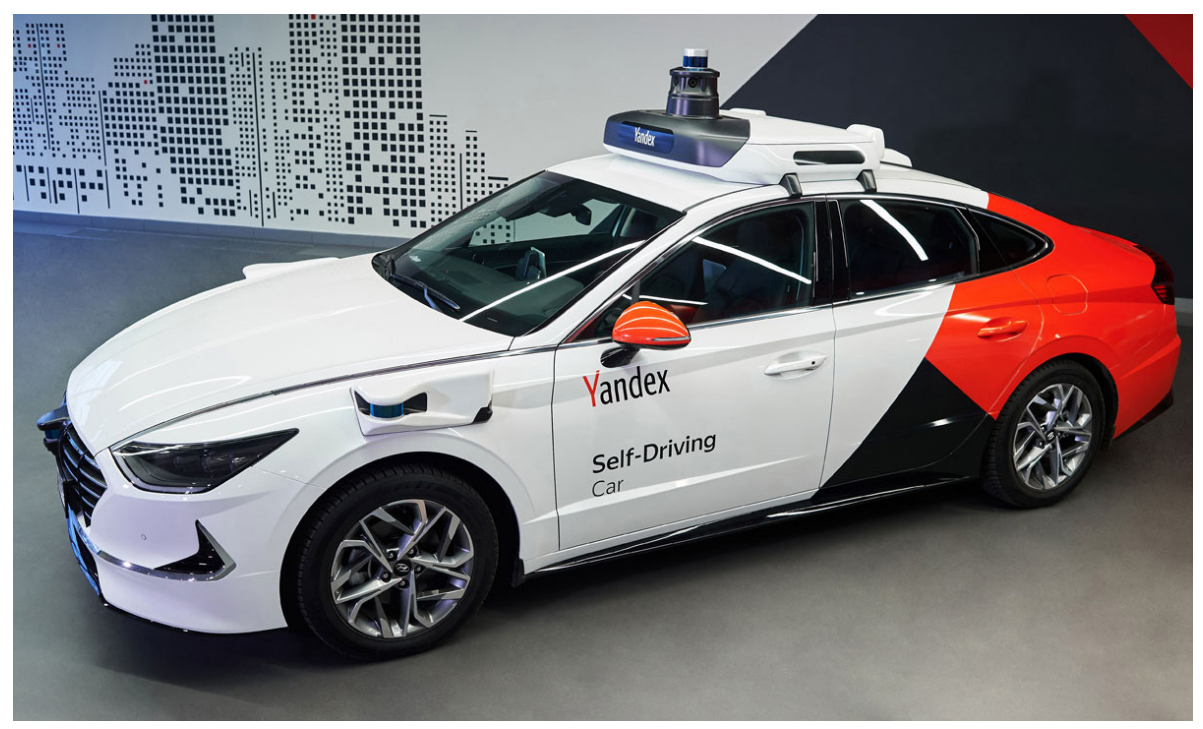

Illustration 1. $4^{\text {th }}$-level HATV

Source: Yandex's corporate blog.

hicles with lower automation levels, this writer believes that they are hardly much different from the situations involving technical failures in 0-level automobiles, which may be caused by manufacturing defects, poor maintenance, the driver's lack of judgment or other factors. Some of these causal factors - for instance, a failure of the stability control due to a defective part in the automobile's brake gear - can warrant the vehicle's owner's filing of a lawsuit against the car maker or the part provider.

The Regulations do not specify the levels of automation implied, although if we systemically interpret the thesaurus in $\$ 3$ of the Regulations, it would be fair to assume that the reference is made to the levels 4 and 5 . The Regulations' requirement that the driver be present in the HATV's driver's seat at all times appears to be of a provisional nature, suitable perhaps to the $3^{\text {rd }}$ automation level, and, one would think, should be omitted from later legal acts, during final stages of the regulatory experiment. Perhaps, as an interim measure, lawmakers could adopt a requirement that the engineer be present in the HATV's passenger compartment but not necessarily in the driver's seat. In the global practice of HATV testing, this level of autonomous driving is usually graded as 4 , whereas level 5 refers to a total absence of the engineer in the passenger compartment.

The Concept of Ensuring Traffic Safety on Public Roads with Driverless Transportation Vehicles (hereinafter referred to as the Concept), adopted 
by the Russian Federation Government in 2020, uses, along with the term HATV, the term "fully automated transportation vehicle" (hereinafter referred to as FATV), describing it as the level 5 vehicle ${ }^{7}$. The Concept also uses the blanket term "driverless transportation vehicle" (DTV), which refers both to HATVs and FATVs; moreover, it has an annex with a table of five levels of autonomous driving in keeping with the SAE International's standards (save level 0).

The issue of terminology in legal regulation of DTVs appears to be important for two reasons. Firstly, definitions introduced in legal acts should be harmonized with administrative law, insurance- and transportationrelated legislation, and road rules. Secondly, Russian legislative innovations should be in keeping, or at the very least not be directly at odds, with supranational regulatory documents, including non-binding ones, related to the use of HATVs. Thus, in the absence of a special general European act on the use of HATVs, some of the relevant issues are addressed in the European Parliament's resolution of 2017 on civil law rules on robotics ${ }^{8}$, the European Commission's 2020 recommendations on regulating $\mathrm{AI}^{9}$, and some other acts. These acts extensively address the questions of ensuring information safety in the process of creating relevant software because it is precisely defects of the software that arguably pose the greatest risks for HATVs. The documents also address the software producers' obligation to take reasonable and sufficient measures to prevent unauthorized interference (hacking) of HATVs.

The issues of compensation for damage in case of traffic accidents involving ordinary vehicles that take place in the EU are regulated by national legislations of the member states, although if the EU authorities continue

7 Instruction No. 724-p of the Russian Federation Government (March 25, 2020). On the Concept of Ensuring Traffic Safety on Public Roads with Driverless Transportation Vehicles [O Kontseptsii obespecheniya bezopasnosti dorozhnogo dvizheniya s uchastiem bespilotnykh transportnykh sredstv na dorogakh obshchego pol'zovaniya]. Compendium of Laws of the Russian Federation [Sobranie zakonodatel'stva Rossiyskoy Federatsii]. March 30, 2020. No. 13, Art.1995.

${ }^{8}$ European Parliament resolution of 16 February 2017 with recommendations to the Commission on Civil Law Rules on Robotics (2015/2013(INL). Available at: https://europarl.europa.eu/doceo/document/TA-8-2017-0051_EN.html (accessed: Oct.1, 2021). The Russian text of this article contains a Russian translation of excerpts from the resolution accomplished by the article's author.

9 European Commission. White Paper on Artificial Intelligence - a European approach to excellence and trust. $\operatorname{Com}(2020) 65$ final. Available at: https://ec.europa.eu/ info/sites/default/files/commission-white-paper-artificial-intelligence-feb2020_en.pdf (accessed: Oct.1, 2021). The Russian text of the article contains a Russian translation of excerpts from the paper accomplished by the article's author. 
to discuss the use of HATVs, the debates can quite possibly lead to the adoption of supranational legal acts in this area as well. The EU lawmakers' efforts to unify national legislations should be taken notice of by their Russian counterparts because presently there hardly exist any objective reasons to ignore the legislative processes in Europe while developing Russian pieces of legislation.

Also noteworthy is the draft of the federal law "On Innovative Transportation Vehicles and on Introducing Amendments to Certain Legal Acts of the Russian Federation" (draft law no. 910152-7) ${ }^{10}$, which was submitted, in 2020, to the Duma by the State Council of the Republic of Tatarstan and which was rejected by the Duma on formal grounds (because the government did not produce an official budget estimate for the law). In the thesaurus of the draft law, the authors of the draft proposed such definitions as an "innovative transportation vehicle," an HATV, and an DTV, with a special legal regulatory framework for each of the three. The innovative transportation vehicle was defined as any transportation vehicle with new structural features (not necessarily related to automated control), and the definitions of HATVs and DTVs essentially corresponded with the $4^{\text {th }}$ and 5 th levels of autonomous driving from SAE International's Standards. This writer believes that the presence of different legislative frameworks for HATVs and FATVs can be useful for addressing issues associated with the imposition of tort liability.

Yet another noteworthy draft of a federal law, "On Highly Automated Transportation Vehicles and on Introducing Amendments to Certain Legal Acts of the RF," was published online in June 2021 on the federal portal where legislative proposals are posted for public consideration ${ }^{11}$. Prepared by Russia's ministry of transportation in cooperation with Yandex SDC and SberAutoTech ${ }^{12}$, this draft is a logical continuation of the legal experiment

${ }^{10}$ A draft of the federal law On Innovative Transportation Vehicles and on Introducing Amendments to Some Legal Acts of the Russian Federation [Ob innovatsionnykh transportnykh sredstvakh i o vnesenii izmeneniy v otdel'nye zakonodatel'nye akty Rossiyskoy Federatsii]. Available at: URL: https://sozd.duma.gov.ru/bill/910152-7 (accessed: Oct. 1, 2021)

11 A draft of the federal law "On Highly Automated Transportation Vehicles and on Introducing Amendments to Some Legal Acts of the Russian Federation" [O vysokoavtomatizirovannykh transportnykh sredstvakh i o vnesenii izmeneniy v otdel'nye zakonodatel'nye akty Rossiyskoy Federatsii]. ID of the draft: 02/04/06-21/00116763. Available at: URL: https://regulation.gov.ru (accessed: Oct. 1, 2021)

12 See, for instance: A Law for Driverless Vehicles [Bespilotnym avto zakon pisan]. Kommersant, June 11, 2021. Available at: URL: https://kommersant.ru/doc/4856110 (accessed: Oct.1, 2021) 
in the use of HATVs on public roads. The key feature of the draft is a provision for operating an HATV without an engineer in the driver's seat - the usefulness of this provision has been discussed above. Art.1 of the draft law contains a detailed thesaurus without, however, differentiating between types of DTVs depending on their level of autonomous driving. In addition to establishing obligations of possessors, operators and manufacturers of HATVs, the draft also provides for amendments to the transportation- and insurancerelated legal frameworks, which presently often do not distinguish between ordinary transportation vehicles and HATVs. Moreover, Art. 3 of the draft prioritizes the Russian Federation's international agreements on the use of HATVs, which include the Vienna Convention and - if a broad interpretation is applied - the mentioned recommendations of the EU.

The ministry of transportation's draft law is in line with the government's Concept and appears to be a very timely document. This writer wants to highlight that the draft, in Art.17, defers the law's coming into force until March 1,2025. The draft's authors, as it seems, expect to use the interim period for elaborating and introducing necessary amendments to the road rules and other acts. Besides, as the period designated for the legal experiment is drawing to a close, Russia's Ministry of Economic Development has produced and published on the federal portal of drafts of legal acts a draft of the governmental Order introducing yet another legal experiment in the use of HATV s ${ }^{13}$, to run for 3 years. The thesaurus provided in the draft identifies " $11^{\text {st }}$ category HATVs," which have a test driver in the driver's seat, and " 2 nd category HATVs," with remote-control routing and operation. So, this legal experiment will probably replace the current one and last from 2022 to 2024.

\section{Liability issues}

This writer agrees with renowned legal scholar V. B. Naumov in that an overproduction of legal acts related to high technologies can result in a lack of legal certainty, when lawmakers, generating reams of norms while ignoring the rules of legislative drafting, create a new disorder instead of bringing order to legal relations [Naumov V.B., Butrimovich Ya. V. et al., 2020: 40-49]. Creating a separate body of law to address violations of the

${ }^{13}$ A draft of the Order of the Government of the Russian Federation "On Introducing the Digital Innovation Experimental Legal Regime and Approving the Use of Highly Automated Transportation Vehicles Programs in Conjunction with this Regime" [Ob ustanovlenii eksperimental'nogo pravovogo rezhima v sfere tsifrovykh innovatsiy i utverzhdenii programm eksperimental'nogo pravovogo rezhima $v$ sfere tsifrovykh innovatsiy po ekspluatatsii vysokoavtomatizirovannykh transportnykh sredstv]. ID of draft: 01/01/0921/00119869. Available at: URL: https://regulation.gov.ru (accessed: Oct.1, 2021) 
road rules by HATVs is unlikely to contribute to traffic safety if these norms cardinally differ from the norms applicable to ordinary transportation vehicles. Such norms should be based, as much as possible, on rules and institutions familiar to drivers, otherwise road users are bound to have hard time assimilating these rules. In this context, road traffic regulation can be called one of the most conservative fields because basic road rules practically have not changed since the time of the first traffic lights and road signs.

In this context, one is reminded of the news of the late $19^{\text {th }}-$ early $20^{\text {th }}$ centuries, when the first road accidents involving steam-driven "selfmoving carriages" were recorded in London, New York, Paris and other big cities. These news items fairly often contained demands to prohibit the use of the vehicles on account of their very high and dangerous speed, which, in case of the most advanced "self-moving carriages," could be as high as $10-12 \mathrm{~km} /$ hour.

In 1861, not without the "help" of the railroad lobby, fearful of losing some of its revenue to producers and operators of steam-driven automobiles, the UK Parliament passed the Locomotive Act ${ }^{14}$, restricting speed for all steam-driven locomotives (which then included automobiles as well) to 10 miles an hour in out-of-town areas and 5 miles an hour in "any City, Town, or Village." Amendments introduced to this law in 1865 reduced the maximum speed to 4 miles an hour out of town and 2 miles an hour in cities, towns and villages; another new provision required that every "steamdriven locomotive" in a city should be accompanied with a man, walking in front of it and carrying a red flag high in his hands, warning pedestrians about the danger; the law was called accordingly — Red Flag Act ${ }^{15}$. These restrictions, reasonable for railroad vehicles but absolutely absurd for automobiles, were lifted only in 1896, when the new Locomotive Act exempted locomotives weighing less than 3 tons from this requirement.

The attempt to place on the same footing a new, unregulated type of transportation vehicles and railroad, a kind of transport well familiar to the public by then, resulted in a period of serious stagnation for British car making industry. In the early $20^{\text {th }}$ century British automotive engineers had to copy works of their German and French colleagues because in Germany and France such restrictions were not imposed, despite the pressure of

${ }^{14}$ Locomotive Act, 1861. Available at: URL: https://legislation.gov.uk/ukpga/Vict/2425/70/enacted (accessed: Oct. 1, 2021)

${ }_{15}$ An Act for further regulating the Use of Locomotives on Turnpike and other Roads for Agricultural and other Purposes, 1865. Available at: URL: https://archive.org/details/ statutesunitedk30britgoog/page/n247 (accessed: Oct. 1, 2021) 
public opinion and lobbying groups. So, British lawmakers' essentially proscriptive policies in relation to first automobiles caused an entire industry to lag far behind similar industries in other countries. One hundred years later, we cannot imagine modern life without cars, and economy, without automotive freight.

Lawmakers nowadays face a largely similar dilemma: to allow the use of HATVs or to artificially retard the sector's development citing as an excuse these vehicles' insufficient safety. If the second alternative is adopted, in the foreseeable future we are certain to need large-volume purchases of driverless vehicles and relevant software from international providers. The choice is difficult, however, because it is impossible to weigh technological progress against hypothetic human casualties which may result from a total absence of restrictions on the use of HATVs. Given this, the key question of legal regulation in the field under review appears to be the question of apportioning liability in road accidents involving HATVs.

Thus, renowned legal scholars N. V. Rumyantsev and V. V. Zhuravlev argue the presumption of the vehicle owner's guilt, which the administrative legislation automatically applies in the cases of (video)recorded administrative violations, can be equally applied to owners of HATVs [Rumyantsev N.V., Zhuravlev V.V., 2020: 196-200]. This writer agrees with the approach whereby in cases of speed violations, or violations of the rules regulating the use of a vehicle's lighting devices, by an HATV the vehicle's owner will have to prove in court that (s)he is not a guilty party.

This approach appears to underpin $\$ 18$ of the mentioned Regulations, as well as the ministry of transportation's draft law, whereby the HATV's owner is responsible for traffic accidents and other accidents on the RF's motor roads involving his/her HATV, in the absence of wrongdoing on the part of other road users that resulted in the accident. The category of other road users should arguably include not only pedestrians and drivers of other vehicles, but also passengers of HATVs utilized by their owners as taxis. Passengers of HATVs will be fully responsible for their wrongful acts, such as, for instance, an attempt to damage the HATV or throwing garbage from a window of the moving HATV. In relation to such passengers the HATV's owner will probably apply additional disciplinary measures such as blocking their accounts and banning the passengers from using the carrier's services in future. So, adjudicating a hypothetical violation of traffic rules by an HATV or a compensation claim arising from a traffic accident involving an HATV, the court will have to assess whether - and if so, to what degree - a person in the driver's seat could regulate the character and 
speed of the HATV's movement. So owners of HATVs should be interested in reducing the probability of such occurrences to zero.

Presently it seems safe to say that Russian companies participating in the legal experiment in the use of HATVs behave themselves very responsibly. A proof of this is the fact that they buy HATV civil liability insurance policies that are several-fold more expensive than the maximum coverage for insurance policies of ordinary vehicles' drivers (up to 10 million rubles against 400,000 rubles of the maximum coverage for mandatory motor insurance). One would think that during the legal experiment owners of "freight" HATVs, too, would be insuring their cargoes for bigger sums than their sector's average.

At the same time, legal scholars A. I. Chuchaev and S. V. Malikov note that when a person in an HATV's driver's seat is treated the same as the driver of an ordinary vehicle, this person is thus assigned a greater responsibility than the HATV's owner because it is the driver's obligation to ensure that the road rules are observed and to prevent traffic accidents. HATVs' owners, in legal scholars' opinion, should rather be held liable for softwarehardware failures that cannot be remedied by drivers [Chuchaev A.I., Malikov S.V., 2019: 117-124]. Besides, nowadays in continental systems of justice, in case of injuries or fatalities resulting from traffic accidents, it is precisely the driver, as an individual, and not the HATV's owner (usually corporate owners) or, much less, artificial intelligence, who would be held criminally liable [Kamalova G.G., 2020: 382-388]. Apparently, when HATVs no longer have drivers in driver's seats (and perhaps when even the idea of "the driver's seat" becomes obsolete), this problem is bound to re-emerge.

European legal researchers in general argue that strict liability should be imposed on HATVs' owners [Engelhard E., de Bruin R., 2018], by analogy with hazardous objects, a category well known to Russian/Soviet legal scholars [Antinomov B.S., 1952]; [Fleishits E.A., 1951, etc.]. Such approach appears justified because the share of road accidents caused by drivers' lack of attention or inadequate state of mind (alcoholic intoxication, overfatigue, etc.) will steadily decline as the share of DTVs on public roads will grow. According to the U.S. National Highway Traffic Safety Administration, which every years analyzes data on more than two million road accidents involving ordinary vehicles, "the critical reason" in $94 \%$ of the accidents is attributed to drivers' errors or non-performance ${ }^{16}$.

\footnotetext{
${ }^{16}$ Critical reasons for crashes investigated in the national motor vehicle crash causation survey. NHTSA, 2018. Available at: https://crashstats.nhtsa.dot.gov/Api/Public/ViewPublication/812506 (accessed: Oct.1, 2021)
} 


\section{Ethical and legal issues}

The issues of criminal liability in the event of injury or fatality caused by an HATV inevitably touch on ethical issues. The largest carmakers claim that the autopilot systems installed in production vehicles of the $2^{\text {nd }}$ and $3^{\text {rd }}$ automated driving levels are as safe as can be and programmed to strictly comply with speed limits and road markings. And yet, speaking about programming, such systems should provide for a choice in emergency situations - for instance, a choice between hitting a pedestrian and hitting an obstruction when emergency braking is insufficient. $4^{\text {th }}$ - and $5^{\text {th }}$-automated driving level HATV can get into such situation as well, and in case with the $5^{\text {th }}$-level HATV the person in the passenger compartment will not even be able to intervene with the controlling algorithm. The probability of such scenario is close, although not equal, to zero, so it should be reflected in the software. Several years ago quite a stir was created when a major German carmaker declared that their autopilot systems in such situations would prioritize lives of the driver and the passengers ${ }^{17}$. For all the seeming inhumaneness of this approach, the carmaker's logic is understandable: there are hardly many buyers for a driverless vehicle which, in case of an emergency, is bound to sacrifice its occupants' life and health.

This problem is a present-day version of the well-known ethical-philosophical dilemma called "the trolley problem": a person has to choose (or evaluate other person's choice) between inaction which is bound to kill several people and an action bound to kill one person but save the rest. The most famous version of this dilemma is the fat man dilemma: when a trolley, racing along a track, is going to run over 5 people in front of it, and to stop the trolley, one has to throw an overweight person on the track. An adaptation of this dilemma to the HATV realities can look like this:

a child crosses the road outside the designated crossing area, getting in the way of an HATV, whose speed and short distance from the child made it impossible to stop without hitting the child;

a child does not see an HATV moving towards him/her nor can (s)he run off to escape the vehicle;

there are no people around who can intervene and save the child;

17 See, for instance: Self-Driving Mercedes-Benzes Will Prioritize Occupant Safety over Pedestrians //Car \& Driver, Oct.7, 2016. Available at: https://www.caranddriver.com/ news/a15344706/self-driving-mercedes-will-prioritize-occupant-safety-over-pedestrians/ (accessed: Oct.1, 2021) 
on the sidewalk, there is an old man - he, too, does not see the HATV and the child, but if the HATV moves aside, it would inevitably run over this man.

To simplify the model, let's add that the HATV does not have any third option because the sidewalk is narrow or because the oncoming lane has vehicles speeding along. The HATV, meanwhile, is sufficiently "intelligent" to understand that the child and the old man cannot avoid the collision but it cannot assess in advance the seriousness of the injuries the pedestrians and the HATV's occupants would suffer as the result of the clash.

Attempting to solve the trolley problem in relation to driverless vehicles, professor A. Wolkenstein from Institute of Ethics, History and Theory of Medicine in Munich concludes that this dilemma should not be applied to regulation of driverless vehicles at all. In his opinion, the moral logic underpinning the trolley dilemma is inapplicable to AI systems, which are constitutionally indifferent to death and, so, cannot make moral choices in principle. Second, whereas participants of the ethical experiments are informed about precise consequences of their decisions, HATVs, let alone developers of their software, can only make guesses about possible consequences of such acts. The numerous experiments in moral psychology, therefore, can hardly be useful for programming HATVs or legislating their operation [Wolkenstein A., 2018: 165, 168]. At the same time, in this writer's opinion, applying even a refined version of the trolley dilemma to HATVs, we can make a significant contribution to the discussion of the ethics of AI's algorithms.

\section{The highest level of autonomous driving}

Nowadays streets of Moscow and Innopolis are plied by delivery robots which are not designed to have a driver. This is so-called rovers, which in the foreseeable future can have a serious impact on the market of delivery services, gradually substituting delivery boys and girls. These rovers do not fit into the road rules' definition of a transportation vehicle or the definition of an HATV in the Regulations and the Concept. Similarly, they hardly fit into the other categories of transportation vehicles referenced in the road rules, such as kick scooters or bicycles, because they are not meant for transportation of people. At the same time, de facto the rovers are road users who ply sidewalks and cross traffic areas, while their software is programmed to comply with the road rules. The users' operational capabilities vis-à-vis the rovers are limited to providing delivery addresses and confirming the delivery receipt, so it will be the delivery robot's owner who will be held liable for harm caused by the machine. 


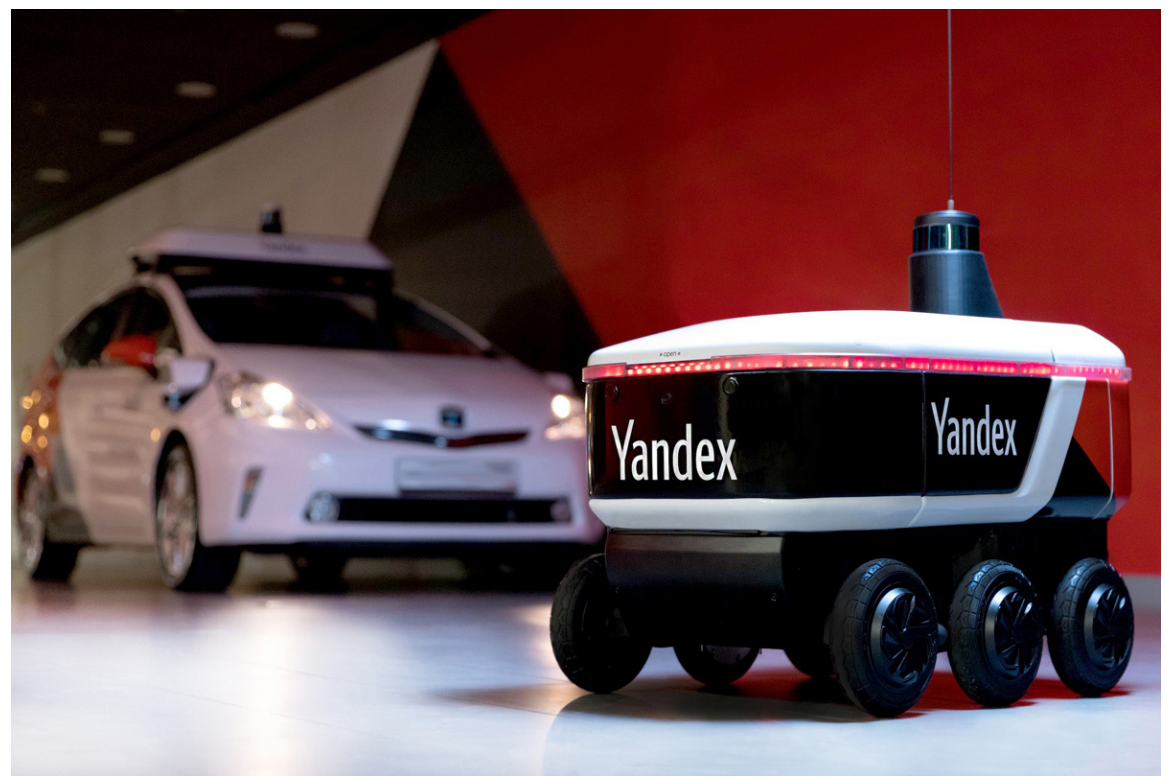

Illustration 2. Yandex Rover Delivery Robot.

Source: corporate blog of Yandex.

That said, in reality, however, more often than not the rovers become "the injured party": not only pedestrians vandalize them pedestrians but car drivers, likewise, quite often hit them in pedestrian crossing areas, at entries to courtyards, on parking lots or on sidewalks. It seems doubtful that such situations should be categorized as a collision between a vehicle and a pedestrian (in the absence of the latter); and yet, they may not only result in a civil lawsuit but also be classified as an administrative offence - for instance, if the car drove on the sidewalk in violation of the road rules. At the present stage of the rovers' technological development, their use hardly requires significant amendments to the legislation, although some issues related to the application of law need to be addressed in judicial opinions. This judicial practice, in turn, can produce legal positions applicable to the regulation of FATVs.

This writer wants to point out an important clarification from court rulings related to the importance of the term "possessor," referenced in Art.1079 of the RF's Civil Code ${ }^{18}$ : "possessor" means an owner of the transportation vehicle or its lawful possessor (someone who controls, manages

${ }_{18}$ Civil Code of the Russian Federation (part 2) (Jan.26, 1996), No. 14-FZ (as amended on March 9 and July 8, 2021). Compendium of Laws of the Russian Federation [Sobranie zakonodatel'stva Rossiyskoy Federatsii], Jan.29, 1996, no. 5, p. 410. 
or otherwise handles the vehicle in any of the numerous other capacities) ${ }^{19}$. The mentioned draft law prepared by the ministry of transportation is based on this notional framework, although attempts to apply this framework to FATV-related tort liabilities brings out a fundamental contradiction: when someone is authorized to manage a FATV by a power of attorney but has no controlling organs at all - can we consider such person the possessor of a hazardous object?

In the foreseeable future, the following hypothetical circumstances can complicate the tort collisions:

a big carmaker buys from third-party producers hardware and software to install in its cars in order to achieve a certain level of autonomous driving capabilities, and these installations break down;

an ordinary automobile's owner himself buys hardware, turning his/her car into a driverless vehicle, and the improperly installed hardware fails;

a DTV's owner does not follow the manufacturer's recommendations for instance, does not update the software, and the equipment breaks down as a result;

the "intelligent road" infrastructure breaks down and a DTV, in response to an incorrect data feed, suffers a traffic accident;

a technical failure causes damage to an HATV's owner who is in the driver's seat - and only to him (for instance, during an idle interval the airbag unnecessarily deploys);

third parties "hack" the software of one or several DTVs, causing traffic accidents with their involvement.

This is far from being a full list of the challenging situations which lawmakers and courts will have to address in the nearest future. Some of the concepts developed for modern FATVs - such as SberAutoTech's Flip, for instance - are much closer to driverless public transport than to personal vehicles because all of the vehicle's occupants are in fact passengers. Here Russian lawmakers could take a leaf from international legal models of passenger transportation in driverless public vehicles - for instance, in Dubai's driverless metro.

$19 \$ \$ 18,19$ of Ruling No. 1, Plenum of the Supreme Court of the Russian Federation. Jan. 26, 2010. On Application by the Courts of the Civil Law Regulating Liability Resulting from Fatalities or Injuries [O primenenii sudami grazhdanskogo zakonodatel'stva, reguliruyushchego otnosheniya po obyazatel'stvam vsledstvie prichineniya vreda zhizni ili zdorov'yu grazhdanina] // Rossiyskaya gazeta. No. 24. Febr.5, 2010. 


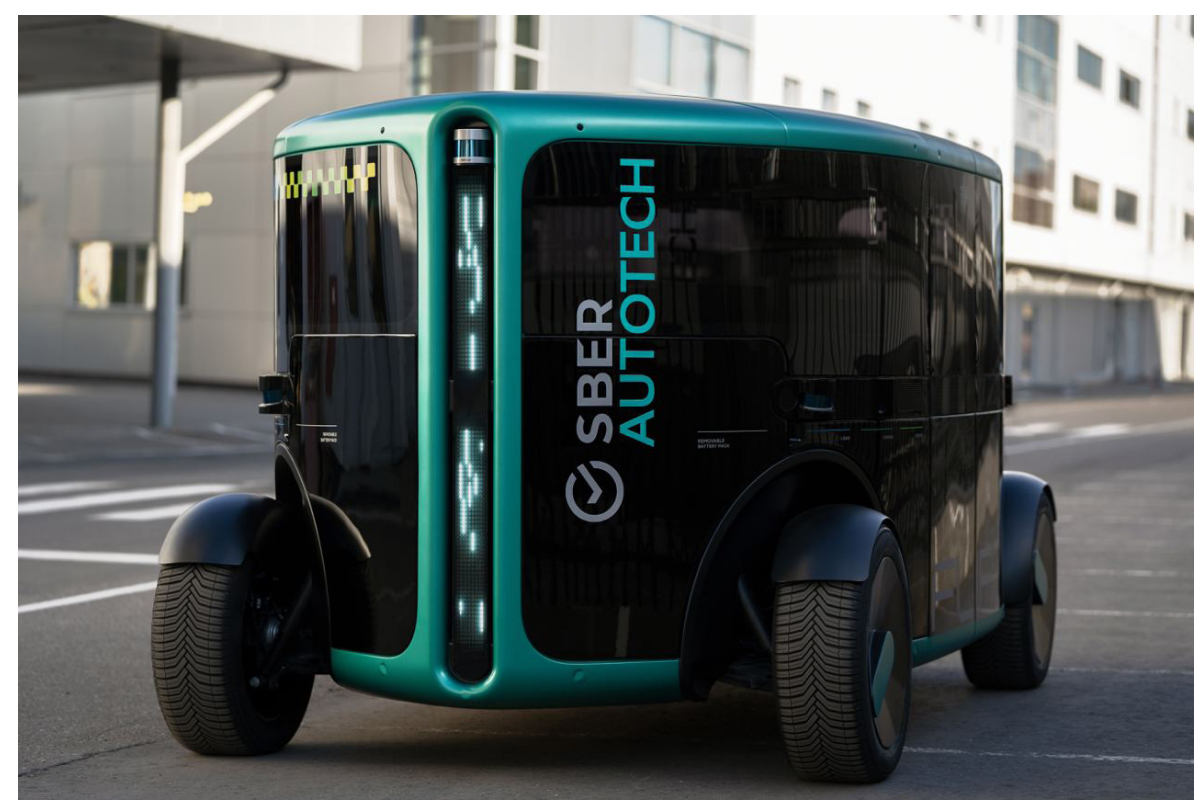

Illustration 3. FATV Flip

Source: official site of Sber ecosystem.

\section{Socio-economic challenges}

The government's Concept anticipates that a large-scale introduction of DTVs would strengthen road traffic safety levels and expects hundreds of billions of rubles in savings resulting from the prevented damage that could have resulted from traffic accidents ${ }^{20}$. It should be noted that these socioeconomic effects are fully in line with the sustainable development goals which should be achieved by 2030, as set forth in UN's document issued in 2015. At the very least, the Concept's provisions arguably correspond with Goal 9 "Industrialization, innovation and infrastructure," Goal 11 "Sustainable cities and communities," and Goal 12 "Responsible consumption and production"21. So, development of driverless vehicles is also in line with our country's main strategic development documents, many of which are in line with UN's sustainable development goals as well.

${ }^{20}$ Section X of the Concept of Ensuring Traffic Safety on Public Roads with Driverless Transportation Vehicles.

${ }^{21}$ For more information, see UN's official site devoted to sustainable development. Available at: https://www.un.org/sustainabledevelopment/https://un.org/sustainabledevelopment/ru/sustainable-development-goals in Russian (accessed: Oct.1, 2021) 
The issues associated with the use of DTVs touch not only on the subject of apportioning tort liability but also on some other issues, such as problems of cyberspace. Thus, a DTV utilized as a taxi is certain to accumulate a wealth of "big user data," ranging from tunes preferred by passengers, their routes, favorite restaurants and stores to reams of videos of streets, other vehicles, and pedestrians (according to SberAutoTech's estimates, one day's worth of data collected by a vehicle amounts to 2 terabytes). In relation to this data, the DTVs' software must be protected in line with the laws on personal data protection and, considering the transborder nature of legal relations, these laws include both Russian ${ }^{22}$ and supranational acts - in particular, the European General Data Protection Regulation (GDPR) ${ }^{23}$. Passengers of DTVs will have to provide informed and voluntary consent to personal data processing; they are also entitled to know what sort of data the HATV's possessor collects and uses. Introducing into the software's (for instance, a mobile application's) algorithm a clause of user's acceptance of the privacy policy of the company possessing the HATV appears to be a fairly formal measure, although this problem is of a general nature and cannot be reduced only to the problem of the use of HATVs.

The anticipated changes will probably include not only the described economic benefits from the large-scale utilization of DTVs for cargo delivery; these developments would arguably have a serious impact on the road infrastructure as well. Road networks and parking spaces in big cities would be used more rationally because HATVs would not have to stand idle for hours waiting for their operators - they can go home, to a gas station or a service station by themselves and then return by the time dictated by the operator. Besides, HATV s have a smoother driving style, which should reduce the fuel consumption level compared to the average vehicle and maybe even improve the environmental situation citywide.

The governmental Concept mentions a number of socio-economic risks associated with the development of DTVs. Labor markets are certain to be affected: taxi drivers and truck drivers in big urban centers may well go the way of chimney cleaners and coachmen. A more delicate handling of

${ }^{22}$ Federal law No. 152-FZ (July 27, 2006; as amended on July 2, 2021) On Personal Data [O personal'nykh dannykh]. Compendium of Laws of the Russian Federation [Sobranie zakonodatel'stva Rossiyskoy Federatsii], July 31, 2006, no. 31 (part 1). Art. 3451.

${ }^{23}$ Regulation (EU) 2016/679 of the European Parliament and of the Council of 27 April 2016 on the protection of natural persons with regard to the processing of personal data and on the free movement of such data, and repealing Directive 95/46/EC (General Data Protection Regulation). Available at: https://eur-lex.europa.eu/legal-content/EN/ TXT/?uri=CELEX:32016R06799 (accessed: Oct. 1, 2021) 
driverless automobiles will significantly reduce the number of their visits to service stations, and in terms of national economy, the subsequent decline in the number of road accidents will affect the structure of workplaces in car care industry and the demand for car parts. This will strongly affect global logistics chains of raw materials extraction and processing and car parts manufacturing and sales. Other professional groups at risk of downsizing include road safety engineers, traffic police and some others. International researchers note, however, that even in the 1940s public discussions of the risks of unemployment caused by technological advancements were so commonplace that newspapers called them "an old topic" [Susskind D., 2020: 40]. Whereas in fact in the $20^{\text {th }}$ century there was perhaps only one profession eliminated by technological revolutions - that of an elevator operator.

At the same time, one cannot rule out the prospect of DTVs giving rise to negative models of social behavior, from "new luddites" protesting against automation of their workplaces to the possible rise of "pedestrians' extremism," when pedestrians, confident that a DTV would pull up and let them cross the street, will en masse stop observing the road rules crossing streets. That said, it is difficult to imagine that in the nearest 10-20 years streets of Russian cities will have DTVs in the numbers necessary to effect such developments.

In the area of traffic safety, developed countries not infrequently adopt programs intended to eliminate the probability of harmful consequences: zero waste - zero polluting emissions from automobiles; vision zero zero fatalities caused by traffic accidents. Although the declared goals are noble, these programs appear somewhat utopian because, in this writer's opinion, using machines, one simply cannot avoid accidents. With that in mind, international risk assessors have conceived and developed the standards such as ALARA (As Low As Reasonably Achievable) and ALARP (As Low As Reasonably Practicable). The only effect of the attempts to perpetuate the zero risk requirement would be a slowing down of the development of these technologies, whereas the ALARA and ALARP principles, which are applied, inter alia, in civil aviation, appear to be the most efficient solution.

\section{Some conclusions}

By way of a conclusion let's say that in addition to the use of HATVs, there are many other technology-driven experiments being carried out on Russian public roads, but no other field project generates so much interest among the public as this one. What explains this is perhaps the fact that 
in mass culture driverless automobiles and robotized public transport are some of the most compelling symbols of the good things technology can bring us in the future. These realities are associated with safety, comfort and economic security while also carrying new risks for the conveniences that humankind is accustomed to, thus generating a public demand for a balanced and fair legal regulatory framework.

As has been aptly noted by philosopher N. V. Stolbova, unlike specialized vehicles, driverless automobiles are integrated into the fabric of everyday life; their presence, their closeness is important for any person irrespective of his/her profession or affiliation with a social group [Komarov S.V., Stolbova N.V. et al., 2019: 58]. Apparently, in the near future driverless automobiles will continue to ply our country's roads and finally will significantly change our tort, insurance and administrative laws.

Conservative-minded people fairly criticize modern drivers for their excessive reliance on electronic assistance systems, low attention levels in the driver's seat, and a lack of technical knowledge about automobiles. But one should not expect that the human skill of car driving will dissolve into redundancy in the nearest decades. It appears more likely that the immediate effects of the development of HATV in the years ahead would include a greater traffic safety, better economic results for the production chains, and environmental improvements.

This writer believes that the logic underpinning the public authorities' actions - the logic that this article explores - deserves support. 2022 will see the end of the current legal experiment in the use of HATVs with engineers in the driver's seat on public roads; this experiment is to be followed, if the necessary order is issued, by a second stage. During this second phase, in 2022-2024, HATVs will first be running with an engineer in the driver's seat and then, in a remote routing mode, operated from the control center. If this phase is successful, in 2025 the amendments to the federal laws fully legalizing the use of HATVs on public roads would come into force.

The appropriate conceptual basis for the emerging legal regulatory framework could be the thesis that all or, at least, the absolute majority of technological innovations, beginning from the most primitive tools, have served a humanist purpose - making people's life easier, saving their energy, time or other resources. As the civilization progressed, relieving people of the need to do physical work, it freed up more and more time and energy for cognitive activity, for spiritual and intellectual development, enhancing the value of a human life grew and facilitating new discoveries. So, protecting the essential civil rights and liberties should be the primary goal for lawmakers to pursue in the new technological environment. 


\section{证国 References}

1. Antimonov B.S. (1952) Tort Liability for Harm Caused by a Hazardous Object [Grazhdanskaya otvetstvennost' za vred, prichinyonnyy istochnikom povyshennoy opasnosti]. Moscow: Uridicheskaya literature. 300 p. (In Russ,).

2. Chuchaev A.I., Malikov S.V. (2019) Responsibility for Damage Caused by a Highly Automated Transportation Vehicle: The Current State of Affairs and Prospects for the Future" [Otvetstvennost' za prichinenie ushcherba vysokoavtomatizirovannym transportnym sredstvom: sostoyanie i perspektivy]. Aktual'nye problemy rossiyskogo prava = Current Issues of Russian Law, no. 6, pp. 117-124. Available at: URL: https://cyberleninka.ru/article/n/otvetstvennost-za-prichinenie-uscherba-vysokoavtomatizirovannym-transportnym-sredstvom-sostoyanie-i-perspektivy (accessed: Oct.1, 2021) (In Russ.).

3. Engelhard E., de Bruin R. (2018) Liability for Damage Caused by Autonomous Vehicles. The Hague: Eleven International publishing. Available at: URL: https://researchgate.net/publication/338431011_book_ on_autonomous_vehicles_2018 (accessed: Oct.1, 2021)

4. Fleishits E.A. (1951) Obligations Originating from the Causing of Damage and Liabilities Originating from Unjustified Enrichment [Obyazatel'stva iz prichineniya vreda i obyazatel'stva iz neosnovatel'nogo obogashcheniya]. Moscow: Gosurizdat, 240 p. (In Russ.).

5. Kamalova G.G. (2020) Some Issues of Criminal Responsibility Associated with Application of Artificial Intelligence Systems and Robotics [Nekotorye voprosy ugolovno-pravovoy otvetstvennosti $v$ sfere primeneniya sistem iskusstvennogo intellekta i robototekhniki]. Vestnik Udmurtskogo universiteta. Seriya "Ekonomika $i$ pravo = Transactions of Udmurt State University. Economy and Law Series, no. 3, pp. 382-388. Available at: URL: https://cyberleninka.ru/article/n/nekotorye-voprosy-ugolovnopravovoy-otvetstvennosti-v-sfere-primeneniya-sistem-iskusstvennogointellekta-i-robototehniki (accessed: Oct.1, 2021) (In Russ.).

6. Komarov S.V., Stolbova N.V., Neznamov A.V., Chudinov O.R. (2019) Review of the Panel Discussion Self-Driving Cars: Moral Challenges and Legal Regulation (Dec.3, 2018) Obzor panel'noy diskussii «Bespilotnye avtomobili moral'nye vyzovy i pravovoe regulirovanie» (03.12.2018). Tekhnologos=Tehnologos, 2019, no. 2, pp. 52-67. DOI: 10.15593/perm. kipf/2019.2.05 Available at: URL: https://cyberleninka.ru/article/n/ obzor-panelnoy-diskussii-bespilotnye-avtomobili-moralnye-vyzovyi-pravovoe-regulirovanie-3-dekabrya-2018-goda/viewer (accessed: Oct.1, 2021) (In Russ.).

7. Lazutkina V.S., Pokusaev O.N., Kupriyanovsky, V.P., Sinyagov S.A.(2019) Economic Effects of Autonomous (Driverless) Cars [Ekonomicheskie effekty avtonomnykh (bespilotnykh) avtomobiley]. International Journal 
of Open Information Technologies, no. 2, pp. 66-80. Available at: URL: https://cyberleninka.ru/article/n/ekonomicheskie-effekty-avtonomnyhbespilotnyh-avtomobiley (accessed: Oct. 1, 2021) (In Russ.).

8. Makarov V.O. (2020) Practical Aspects of the Introduction of Regulatory Sandboxes into the Russian Legislation in the Context of the Coming into Force of Federal Law 258-FZ On Digital Innovation Experimental Legal Regimes in the Russian Federation'" [Prakticheskie voprosy vnedreniya instituta regulyativnykh pesochnits v rossiyskoe zakonodatel'stvo v kontekste vstupleniya v silu federal'nogo zakona ot 31.07.2020 N 258FZ “Ob eksperimental'nykh pravovykh rezhimakh v sfere tsifrovykh innovatsiy v Rossiyskoy Federatsii"]. Yuridicheskie issledovaniya = Legal Research, 2020, no. 11, pp. 18-24. Available at: URL: https://cyberleninka. $\mathrm{ru} /$ article/n/prakticheskie-voprosy-vnedreniya-instituta-regulyativnyhpesochnits-v-rossiyskoe-zakonodatelstvo-v-kontekste-vstupleniya-vsilu (accessed: Sept.1, 2021) (In Russ.).

9. Naumov V.B., Butrimovich Ya.V., Kotov A.A. (2020) Ensuring a High Quality of Legal Regulation of Experimental Legal Regimes [Obespechenie vysokogo kachestva pravovogo regulirovaniya eksperimental'nykh pravovykh rezhimov]. Rossiyskoe pravo: obrazovanie, praktika, nauka $=$ Russian Law: Educaton, Practice, Scholarship, no. 3, pp. 40-49. Available at: URL: https://cyberleninka.ru/article/n/obespechenie-kachestva-pravovogo-regulirovaniya-eksperimentalnyh-pravovyh-rezhimov (accessed: Oct. 1, 2021) (In Russ.)

10. Neznamov A.V. (2018) Rules of Autonomous Driving: On Amendments to the Convention on Road Traffic [Pravila bespilotnogo vozhdeniya: ob izmeneniyakh Venskoy konventsii o dorozhnom dvizhenii]. Zakon = Law, no. 1, pp. 172-182. (In Russ.).

11. Rumyantsev N.V., Zhuravlev V.V. (2020) Administrative Regulation of Highly Automated Transportation Vehicles on Public Roads [Administrativno-pravovoe regulirovanie uchastiya vysokoavtomatizirovannykh transportnykh sredstv v dorozhnom dvizhenii]. Vestnik ekonomicheskoy bezopasnosti=Newsletter of Economic Safety, no. 5, pp. 196-200. Available at: URL: https://cyberleninka.ru/article/n/administrativno-pravovoe-regulirovanie-uchastiya-vysokoavtomatizirovannyh-transportnyhsredstv-v-dorozhnom-dvizhenii (accessed: Oct.1, 2021) (In Russ.).

12. Shadrin S.S., Ivanova A.A. (2019) Analytical Review of SAE Standards J3016 Taxonomy and Definitions for Terms Related to Driving Automation Systems for On-road Motor Vehicles' with Latest Updates [Analiticheskiy obzor standarta SAE J3016 Klassifikatsiya, termina i opredeleniya sistem avtomatizirovannogo upravleniya dvizheniem ATS s uchyoetom poslednikh izmeneniy]. In: Avtomobil. Doroga. Infrastructura = Automobile. Roads. Infrastructure, no. 3. Available at: URL: https://adi-madi.ru/ madi/article/viewFile/811/pdf_478 (accessed: Oct.1, 2021) (In Russ.).

13. Shaklein A.G., Pokusaev O.N., Kupriyanovsky V.P., Ovsyannikov M.L., Lazutkina V.S. (2019) The Motives for the Use of Autonomous (Driverless) Cars in the EC and the USA [Motivy vnedreniya avtonomnykh (be- 
spilotnykh) avtomobiley v EC i SShA]. International Journal of Open Information Technologies, no.1, pp. 104-114. Available at: URL: https:// cyberleninka.ru/article/n/motivy-vnedreniya-avtonomnyh-bespilotnyhavtomobiley-v-ec-i-ssha (accessed: Oct.1, 2021) (In Russ.).

14. Susskind D. (2021) A World Without Work: Technology, Automation, and How We Should Respond [Mir bez raboty. Tekhnologiya, avtomatizatsiya i stoit li ikh boyat'sya]. Moscow: Individuum, p. 40. (In Russ.)

15. Voronin D.A., Makarevich M.L. (2018) Some Issues of Legal Regulation of Self-Driving Vehicles [Problemy pravovogo regulirovaniya avtonomnogo transporta]. Innovatsionnaya ekonomika: perspektivy razvitia $i$ sovershenstvovania = Innovation Economy: Prospects of Development and Improvement, no. 7, vol. 1, pp. 123-128. Available at: URL: https://cyberleninka.ru/article/n/problemy-pravovogo-regulirovaniyaavtonomnogo-transporta (accessed: Oct.1, 2021) (In Russ.).

16. Wolkenstein A. (2018) What Has the Trolley Dilemma Ever Done For Us (And What Will It Do in the Future)? On Recent Debates about the Ethics of Self-Driving Cars". Ethics and Information Technology, vol. 20, no 3, pp. 163-173.

\section{Information about the author:}

A.G. Deineko - Candidate of Sciences (Law), Professor, Associate Member of the UNESCO Chair on Copyright, Related, Cultural and Information Rights, State Councellor of the Russian Federation, $2^{\text {nd }}$ class.

The article was submitted 20.10.2021; approved after reviewing 25.10.2021; accepted for publication 01.11.2021. 